\title{
Editorial
}

\section{Bacterial Infections in Patients with Cirrhosis Admitted to the Hospital}

\author{
Filipe Sousa Cardoso \\ Intensive Care Unit, Curry Cabral Hospital, Central Lisbon Hospital Center, Nova University, Lisbon, Portugal
}

Keywords

Peritonitis · Sepsis · Liver

\section{Infecções bacterianas em doentes com cirrose admitidos no hospital}

\section{Palavras Chave}

Peritonite · Sépsis · Fígado

Bacterial infections are frequently diagnosed in advanced cirrhosis and are associated with the development of organ failure (acute-on-chronic liver failure) and worse survival $[1,2]$.

In their work, published in this issue, Gomes et al. [3] retrospectively studied the prevalence of bacterial infections in a single-center large sample of patients with cirrhosis and bacterial infections admitted to a medical ward from 2008 to 2014 ( 372 out of 964 admissions in noncontinuous years). Their main findings were the following: (1) overall, the most frequent infections diagnosed were urinary tract infection $(n=121 ; 32.5 \%)$, respiratory tract infection $(n=109 ; 29.3 \%)$, and spontaneous bacterial peritonitis $(n=97 ; 26.1 \%) ;(2)$ overall, bacteria were identified in 198 (53.2\%) cases, with 124 (62.6\%) of those be-

\section{KARGER}

E-Mail karger@karger.com www.karger.com/pig
(C) 2019 Sociedade Portuguesa de Gastrenterologia Published by S. Karger AG, Basel

Karger

Upen access

This article is licensed under the Creative Commons AttributionNonCommercial-NoDerivatives 4.0 International License (CC BYNC-ND) (http://www.karger.com/Services/OpenAccessLicense). Usage and distribution for commercial purposes as well as any distribution of modified material requires written permission. ing Gram negative; (3) from 2008 to 2014, while the prevalence of community-acquired infections increased (49.0 vs. $70.7 \%)$, the prevalence of nosocomial infections decreased (51.0 vs. 29.3\%); (4) from 2008 to 2014, the prevalence of multiresistant bacteria increased (9.6 vs. $14.4 \%)$ - overall, $77.8 \%(42 / 54)$ of those cases were nosocomial; (5) from 2008 to 2014, while the median MELD score decreased (17 vs. 14 ), the in-hospital mortality rate increased (7.0 vs. $25.0 \%$ ).

The findings of Gomes et al. [3] provide a real-life characterization of the current epidemiology of bacterial infections in patients with cirrhosis admitted to a large district hospital in the north of Portugal. Furthermore, they emphasize some key characteristics of bacterial infections in this group of patients [4]: they are frequent (38.6\% of ward stays), but a positive microbiological diagnosis is often lacking (46.8\%); therefore, a great deal of clinical suspicion is needed to make the working diagnosis; in a cohort of patients admitted to the ward largely from the emergency department (89.5\%), Gram-negative and nonresistant bacteria are still preponderant; thus, current protocols of antimicrobial treatments may still apply effectively.

Despite all of this, the findings of Gomes et al. [3] raise several questions. The first one is: why is nosocomial infection rate decreasing over time? As some relevant fac- 
tors to this discussion were not provided (e.g., history of antibiotic exposure or invasive procedures), it is not easy to find answers in this report. Therefore, may there be any specific hospital-led program ongoing dedicated to mitigating the risk of in-hospital acquired infection? If so, this may point out the real benefit of investing time and resources in such type of programs [5].

Another question is: why is hospital mortality on the rise? Despite their efforts, Gomes et al. [3] did not provide a robust answer to this question either. Therefore, we can only speculate about the real justification for this fact. Is it related to patients' comorbidities, complications of infection and access to higher levels of care, complications of portal hypertension, or even access to timely assessment for liver transplantation?
As important questions obviously remain unanswered, we can only hope that future studies with the collaboration of several national centers treating patients with cirrhosis, and with the help of specific medical societies, will shed some light on those ambiguous topics.

\section{Disclosure Statement}

The author has no conflicts of interest to declare.

Funding Sources

None.

\section{References}

1 Fernández J, Acevedo J, Castro M, Garcia O, de Lope CR, Roca D, et al. Prevalence and risk factors of infections by multiresistant bacteria in cirrhosis: a prospective study. Hepatology. 2012 May;55(5):1551-61.

2 Moreau R, Jalan R, Ginès P, Pavesi M, Angeli $\mathrm{P}$, Cordoba J, et al.; CANONIC Study Investigators of the EASL-CLIF Consortium. Acuteon-chronic liver failure is a distinct syndrome that develops in patients with acute decompensation of cirrhosis. Gastroenterology. 2013 Jun;144(7):1426-37.
3 Gomes CL, Silva RV, Carrola P, Presa J. Bacterial infections in patients with liver cirrhosis in an internal medicine department. GE Port J Gastroenterol.2018,DOI: 10.1159/000494568.

4 Oliveira AM, Branco JC, Barosa R, Rodrigues JA, Ramos L, Martins A, et al. Clinical and microbiological characteristics associated with mortality in spontaneous bacterial peritonitis: a multicenter cohort study. Eur J Gastroenterol Hepatol. 2016 Oct;28(10):1216-22.

5 Jalan R, Fernandez J, Wiest R, Schnabl B, Moreau R, Angeli P, et al. Bacterial infections in cirrhosis: a position statement based on the EASL Special Conference 2013. J Hepatol. 2014 Jun;60(6):1310-24 